\title{
Isolamento do vírus rábico de morcego insetívoro Myotis nigricans
}

\author{
Isolation of the rabies virus in a specimen of the insectiverous bat Myotis \\ nigricans
}

\author{
Luzia F. A. Martorelli, Elizabeth A.C. Aguiar, Marilene F. Almeida, Miriam M.S. Silva, \\ Eliana C. R. Novaes
}

Centro de Controle de Zoonoses da Prefeitura do Municipio de São Paulo - Brasil (L.F.A.M.; E.A.C.A.; M.F.A.; M.M.S.S. Unidade de Vigilancia Sanitária de Ribeirão Pires - Brasil (E.C.R.N.)

\begin{abstract}
Relata-se um caso de infecçāo natural de raiva em morcego insetivoro Myotis nigricans, no Municipio de Ribeirão Pires, Grande Săo Paulo (Brasil). O diagnóstico realizou-se através das técnicas de imunofluorescéncia $\theta$ inoculaçāo intracerebral em camundongos, do tecido nervoso e da musculatura da regiāo interescapular do morcego.
\end{abstract}

Vírus da raiva, isolamento \& purificação. Quiropteros. Raiva, transmissāo.

No dia $21 / 06 / 94$, por volta das $18: 00 \mathrm{~h}$, no bairro Jardim Caçula, área peri-urbana, Município de Ribeirão Pires, SP, duas crianças, com aproximadamente 10 anos de idade, observaram um morcego em pleno vôo. Com uma vara atingiram o animal, derrubando-o ao solo. Com auxílio de uma folha, o morcego foi colocado, ainda vivo, dentro de um vidro. No dia seguinte, por iniciativa de uma das crianças, o animal foi levado à Unidade de Vigilância Sanitária que o encaminhou ao laboratório do Centro de Controle de Zoonoses, para diagnóstico de raiva e identificaçāo da especcie.

O diagnóstico realizou-se através das técnicas de imunofluorescência direta ${ }^{2}$ e inoculação intracerebral em camundongos ${ }^{6}$. $\mathrm{O}$ isolamento do vírus da raiva foi obtido de duas regiões do organismo do morcego: cérebro e tecido muscular da regiâo interescapular, considerada por alguns autores como uma região potencialmente importante ${ }^{1,3}$.
Apesar de o animal estar muito danificado, foi tentado, sem sucesso, o isolamento do vírus da região da musculatura das glândulas salivares $\mathbf{e}$ traquéia, objetivando poder observar a transmissâo do vírus por via salivar ${ }^{1,3}$.

O morcego capturado era um macho, pesando $3,5 \mathrm{~g}$, medindo aproximadamente $4,2 \mathrm{~cm}$, de cor castanha e de hábito alimentar insetivoro ${ }^{4}$, pertencente à Família Vespertilionidae do gênero Myotis nigricans.

Destaque-se que o Município de Ribeirão Pires năo notificou nenhum caso de raiva humana ou animal, desde 1984, segundo o Centro de Vigilância Epidemiológica do Estado de São Paulo.

Por outro lado, sabe-se que na regiano ocorre grande número de morcegos, inclusive hematófagos, não só na periferia, como no centro da cidade. Sendo espécies noturnas, necessitam durante o dia de abrigos utilizando-se para tanto de $\alpha \cos$ de árvores, forros, porōes, śț̄̄os, juntas de dilatação e outros espaços construtivos. 
O bairro Jardim Caçula, local de captura do morcego, é uma área peri-urbana que ainda possui mata preservada, distante cerca de dois $\mathrm{km}$ do centro da cidade e próximo à represa Billings.

\section{Referênclas Bibllográflcas}

1. CONSTANTINE, D.G. Health precautions for bat researches. In: Kunz, T.H. Ecological and bebavtoral methods for the study of bats. Washington, Smithsonian Inst. Press, 1988. p. 491-521.

2. IARGHI, O.P. Anticterpos fluorescentes para rábia. Buenos Aires, Centro Panamericano de Zoonoses, 1975 (Nota técnica número 08, Rev. 2),

3. NIISSON, M.R. \& NAGATA, C.A. Isolamento do vírus rábico do cérebro, glândulas salivares e interescapular, coração pulmỏes e testículos
As condiçð̄es existentes naquele local parecem adequadas à permanência dos morcegos, uma vez que encontram abrigos e abundância alimentar, favorecendo o contato entre esses, pessoas e animais domésticos.

de morcegos Desmodus rotundus, no Estado de São Paulo. Arq. Inst. Biol,42: 183-8, 1975.

4. NOWAK, R.M. Order Chiroptera. In: Walker, E.P. Mammals of the world. 5a. ed. Baltimore, John Hopkins Univ. Press, 1991. p. 330-6.

5. VIZOTTO, L.D. \& TADDEI, V.A. Chave para determinação de quirópteros brasileiros. Rev. Fac. Filos. Ciên. Letr. S. José do Rio Preto, Bolm. Ciênc. 1:1-72, 1973.

6. WEBSTER, L.T. \& DAWSON, J.R. Early diagnosis of tabies by mouse inoculation: measurement of humoral immunity to rabies by mouse protection test. Proc. Soc. Biol. Med., 32: 570-3, 1935.

\begin{abstract}
The following is a case study of the natural infection by the rabies vins of an insectiverous bat belonging to the species Myotis nigricans in the municipality of Ribeira.o Pires, Greater S. Paulo. Diagnosis was made by means of immunoffuorescence and intracerebral innoculation of mice with nervous and intrascapular muscular tissues.
\end{abstract}

Rabies virus, isolation. Chiroptera, microbiology. Rabies, transmission. 